\title{
Sports' Role in Education for Sustainable Development: Prospective
}

\author{
Sung-Sang $\mathrm{Yoo}^{1}$ \& Hosung So ${ }^{2}$ \\ 1 Seoul National University, South Korea \\ 2 California State University, San Bernardino
}

\section{Introduction}

There is no doubt that sport has taken pivotal parts in development and peace as people gather for fair competitions and friendship sharing, regardless their belongings by gender, race, age, ethnicity, ideology, and nationality (UNOSDP, 2015; Wilson, 2012).

Keywords: sustainable development Goals, physical education, sport

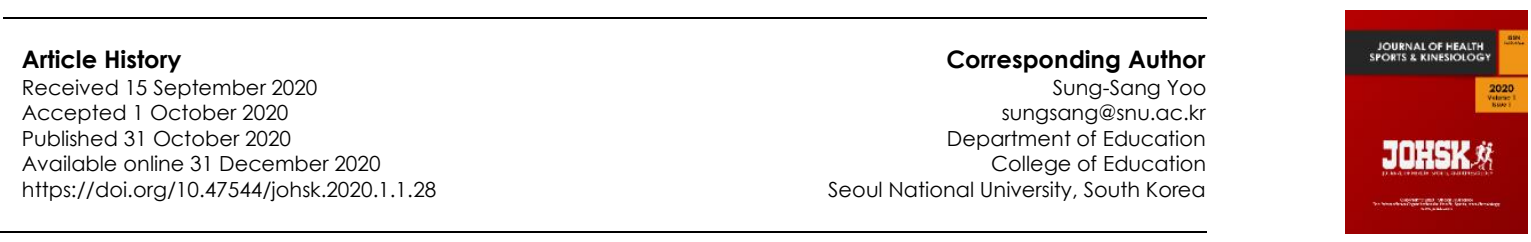

\section{Sport for Sustainable Development}

Sport was highly recognized and became a significant component of international efforts to achieve genuine development as the United Nations set out the 2030 agenda as a shared blueprint and framework for sustainable development, entitled "Sustainable Development Goals (SDGs) in 2015 (see Figure 1)." It is succinctly described as:

"Sport is also an important enabler of sustainable development. We recognize the growing contribution of sport to the realization of development and peace in its promotion of tolerance and respect and the contributions it makes to the empowerment of women and of young people, individuals and communities as well as to health, education and social inclusion objectives" (UNOSDP, 2015, p. 1).

It is not only limited to the goal for 'ensuring healthy lives and promoting well-being for all at all ages (Goal 3)' as a key concerning area, but also every target in 17 goals of SDGs, including poverty reduction, education for all, and sustainable energy that is highly connected and related to the contribution of sports for development (Collison, 2018; UNOSDP, 2015). When international competitive games, such as the Olympics, made peaceful paths toward inclusive and compassionate culture to the world even during the time of physical conflicts, more hopeful role of sports to play are wanted in this enduring-hard time as a key agency for development and peace for all. 
| 2020 | Volume 1 | Issue 1 | The Journal of Health, Sports, and Kinesiology |

\section{Gaps Between Rhetoric and Practice}

It was 1978 that the UN declared that "spots and physical education was a fundamental right for all" and the UN Office on Sport for Development and Peace (UNOSDP) was established in 2001 to support the agenda. Since then, international organizations designated to the agenda, such as UN, UNDP, UNESCO, UNICEF, and ILO have continuously worked to spur sport to deepen and widen the degree of peace with many sports bodies until the SDGs were emerged. By this, sport was highly expected to play a powerful role in international development and peace.

However, the expectation to sport in international level has hardly been achieved while more athletic games took place with record-breaking participants every time (Coakley, 2009). There has been limited and unstructured framework to measure how sport contributes to international concerns in the development and peace. Scholarly works to problematize the role of sport in development and peace, according to the proclaimed agenda by the UN, criticize that sport has been manipulated by the power with various types of capital, national interest-driven sports games harshly deteriorated physical surroundings in communities, and current sport practice and structures scarcely reflect its expected role in inclusiveness and peace (Darnell, 2012; Wilson, 2012). Although most criticisms related to such problems have targeted against ideologically dominant groups to control sport in national and global level, investigations on the role of sport, physical education, and physical activity in community level are quite few to reveal its critical part in development.

In short, as the claim that sport needs to get engaged in international development and peace is undoubtedly high on one hand, the actual practice and involvement of sport, physical education and physical activity to the agenda in various dimensions remain dormant. It is obvious that more actions need to be put into place as it has long been claimed for.

\section{Sport and Education for the Same Goal}

In the meantime, sport cannot be separated from education as education retains a cross-cutting aspect for international development by calling for formulating learning communities. As sport has primarily something to deal with healthy body and sound mind, education could facilitate and fill those with innovative knowledge and imaginative reckoning based upon them. The SDGs also claim that the education should be globally and locally recognized to connect human actions in daily lives to idealism under which the right to learn cannot be obstructed at any time and place by appearance. Then, both sport and education need to be taken as a significant avenue toward global development as they are closely interrelated with every aspect of problematic situations globally spread (Lemke, 2020).

In this context, sport together with education is necessarily supposed to be involved more actively and widely in international development and cooperation, while sport itself has traditionally conceived as games for excellence and pride among elite athletes. However, it is critically necessary to perceive the role of education in development as mentioned in regards with sport's roles.

Despite people's quest for hope and potential progressive transformation in, through and by education and as described in McCloskey's (2015) viewpoints on the important role of education in fostering transitions to sustainability, education mainly functions to make a given societal structure unchanged. Therefore, there is not a clear-cut direction of such a chronological and persistent reforms of education potentially to attain better system of teaching and learning for all since public schooling as a system was pursued (Ravitch, 2016).

However, education has been widely recognized as an active area to deliver quality education to developing countries from early child-care and education (ECCE) to tertiary education to youth and adult education. One of the evidences that could be applied to physical education including physical activities and sports as an important part of education and school curriculum is "Education for Sustainable Development (ESD) that is commonly understood as education encouraging changes in knowledge, skills, values and attitudes to enable a more sustainable and just society for all (UNESCO, 2018).

Moreover, UNESCO and OECD have deeply been engaged in the process of education development by providing adequate support and setting off framework for evaluation. In addition, various tools for policy making and advocacy in local community in developing countries have been disseminated to ensure that education as an unalienable right will be put into action. Then, sport as a global agenda for development needs to move forward beyond well-recognized field competition upon a given ground.

Journal of Health Sports \& Kinesiology | ISSN 2692-9864 | www.johsk.com 


\section{SUSTAINABLE G'MALS}
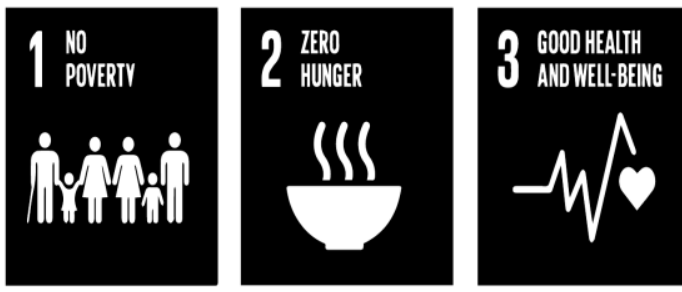

7 AFFORDABLEAND

CLEAN ENERGY
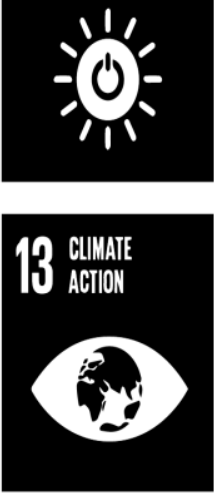

O DEEENTWORK AND

0 ECONOMCGROWTH
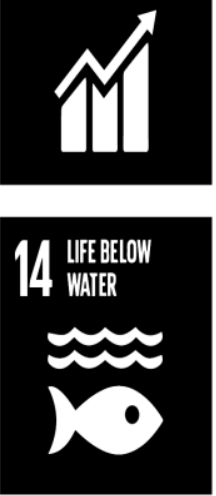

INOUSTRY, NNOVATON
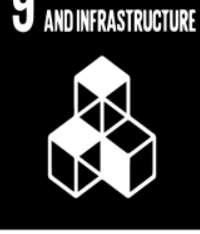
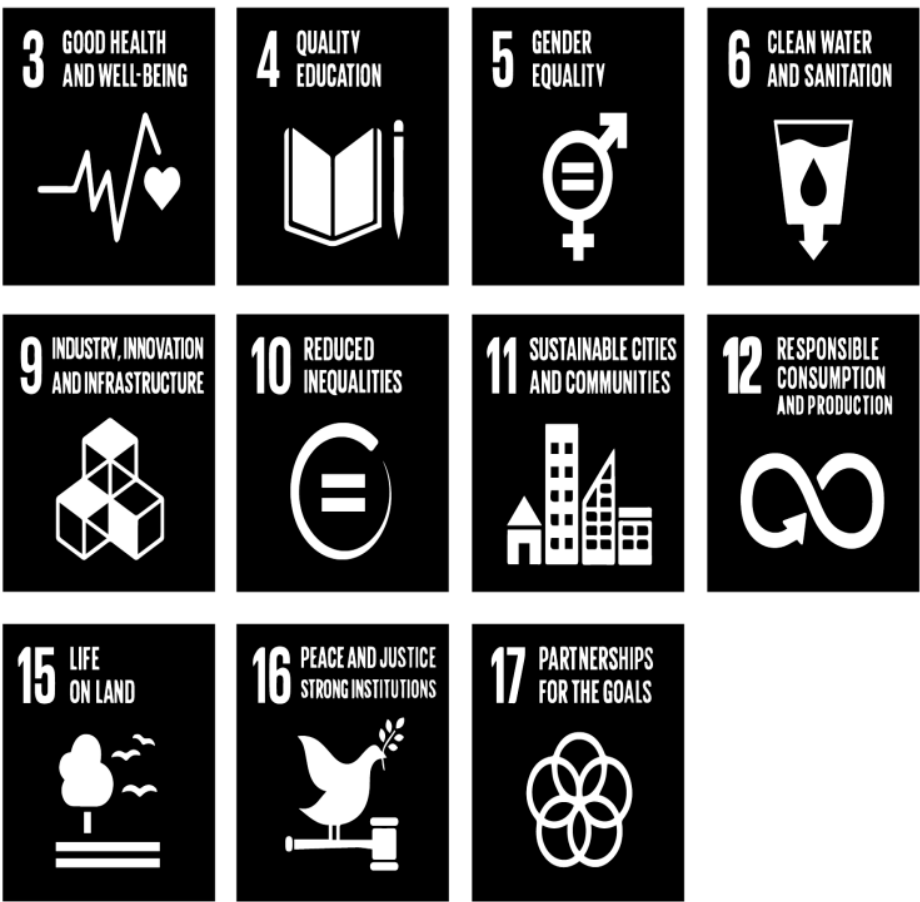

PARTNERSHIPS

FOR THE GOALS
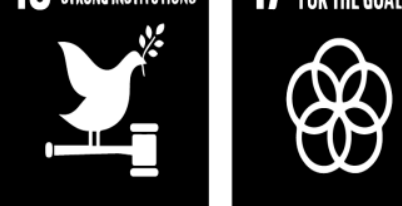

Figure 1 Sustainable Development Goals (SDG), Reprinted from

https://www.un.org/development/desa/disabilities/about-us/sustainable-development-goals-sdgs-anddisability.html

\section{Conclusion}

\section{Prospective Role of Sports in Sustainable Development}

It is necessary and urgent that sport, physical education, and physical activity seriously play its role in international development and peace. As international development and cooperation is an interdisciplinary area of actions, sport needs to get more actively involved and be part of various activities for genuine development in local, national, and international level. More involvement particularly in education development through sport, physical education, and physical activity in developing countries can be advocated for each government to employ. Sport for international development cannot stay as a rhetoric but maintain its power to put every social sectors and factors together for more right-based development, which we believe is an authentic education itself. 


\section{References}

Coakley, J. (2009). Sports in society (10 th ed.). New York: McGraw Hill Higher Education.

Collison, H. (2018). Strengthening the global framework for leveraging sport for development and peace. Report prepared for the United Nations Department of Economic and Social Affairs (UNDESA) and the Division for Inclusive Social Development (DISD, pp. 1-13), Loughborough University London.

Darnell, S. (2012). Sport for development and peace: A critical sociology. London and New York: Bloomsbury Academic.

Lemke, W. (2020). The role of sport in achieving the sustainable development goals. UN Chronicle. Retrieved from https://www.un.org/en/chronicle/article/role-sport-achieving-sustainable-development-goals

McCloskey, S. (2015). Viewpoint: From MDGs to SDGs: We need a critical awakening to succeed. In S. McCloskey (Ed.), Policy and practice: A development education review (pp. 186-194). Carson, CA: Center for Global Education.

Ravitch, D. (2016). The death and life of the great American school system: How testing and choice are undermining education (3rd ed.). New York: Basic Books.

UNESCO. (2018). Issues and trends in education for sustainable development. In A. Leicht, J. Heiss, \& W. J. Byun (Eds.), Key themes in education for sustainable development (pp. 61-86). Paris: The United Nations Educational, Scientific and Cultural Organization Publishing.

UNOSDP. (2015). Sports and the sustainable development goals: An overview outlining the contribution of sports to the SDGs. Retrieved from

https://www.un.org/sport/sites/www.un.org.sport/files/ckfiles/files/Sport_for_SDGs_finalversion9.pdf

Wilson, B. (2012), Sport and peace: A sociological perspective. Ontario, Canada: Oxford University Press.

\section{Journal of Health Sports \& Kinesiology | ISSN 2692-9864 | www.johsk.com}

